\title{
Cachaça Production in Brazil and its Main Contaminant (Ethyl Carbamate)
}

\author{
João Henrique do Nascimento e Silva ${ }^{1 \oplus}$, Marta Regina Verruma-Bernardi1 ${ }^{\oplus}$, Alessandra Lopes de Oliveira ${ }^{2 *} \odot$
}

\author{
'Universidade Federal de São Carlos/Centro de Ciências \\ Agrárias, Rod. Anhanguera, km 174 - 13600-970 - Araras, \\ $\mathrm{SP}$ - Brasil. \\ 2Universidade de São Paulo/FZEA - Depto. de Engenharia \\ de Alimentos, Av. Duque de Caxias Norte, 225 - 13635-900 \\ - Pirassununga, SP - Brasil. \\ *Corresponding author <alelopes@usp.br>
}

Edited by: Luís Guilherme de Lima Ferreira Guido

Received April 23, 2018

Accepted September 07, 2018

\begin{abstract}
This review aims to demonstrate the possible formation of Ethyl carbamate (EC) in different production stages of cachaça. $\mathrm{EC}$ is a carcinogen confirmed in animal experiments and possibly carcinogenic to humans. EC incidence below relevant health limits naturally affects many fermented foods and beverages. Concentrations above $1 \mathrm{mg} \mathrm{L}^{-1}$ are often detected in certain spirits derived from cyanogenic plants. In Brazil, cachaça is widely consumed and therefore consumers are at health risk if they drink $\mathrm{EC}$ beverages at high concentrations, since the amount of EC in cachaça (sugar cane brandy) constantly exceeds the threshold $0.21 \mathrm{mg} \mathrm{L}^{-1}$, damaging the health of consumers and hindering exportation to North America and Europe. Many studies have reported on EC formation at different stages of the cachaça production process. Most studies refer to $\mathrm{EC}$ formation during fermentation and distillation. In fermentation, reaction occurs between ethanol and nitrogen precursors, such as urea $\left(\mathrm{H}_{2} \mathrm{NCONH}_{2}\right)$ and cyanide $\left(\mathrm{CN}^{-}\right)$to form EC. In distillation, cupric ions catalyze cyanide conversion from EC; however, in discontinuous distillation, the bottling fraction of cachaça reduced EC concentration. Although this review describes the possible routes of EC formation at different production stages of cachaça, it presents some studies on $\mathrm{EC}$ reduction in alcoholic beverages.
\end{abstract}

Keywords: sugarcane, spirits, quality, beverage, public health

\section{Introduction}

Sugarcane is one of the most predominant crops in tropical countries and raw material for various products worldwide, such as sugar, ethanol, and cachaça (Silva et al., 2014).

Sugarcane is used to produce cachaça, a Brazilian spirit highly appreciated in Brazil, Europe, and South and North America. Cachaça production in Brazil amounted to 1.8 billion liters in 2015 of which only $1 \%$ exported, roughly 15 million liters, produced by more than 40,000 producers. This production generated 6,000 direct jobs with an annual income of US\$ 2 billion (MAPA, 2005). Recent data show that Brazil has an installed capacity to produce approximately 1.2 billion liters of cachaça per year; however, Brazilian output is less than 800 million liters and exportation reaches 8.7 million liters produced by almost 12,000 producers. Of these, only 2,000 establishments registered at the Ministry of Agriculture and Federal Revenue show that although $90 \%$ of the production is legalized, it is estimated that $85 \%$ of producers are informal, mostly micro and small producers (IBRAC, 2017).

This work describes challenges in the beverage sector, such as research that sets limits, identifies precursors and develops methods of the EC analysis. The use of Good Manufacturing Practices (GMP) in distilleries to control beverage quality has produced positive effects, increasing the levels of volatile compounds in cachaça. Another challenge was to limit the use of copper $(\mathrm{Cu})$ in distillation apparatus and equipment, since $\mathrm{Cu}$ leaves residues in the beverage, causing health problems to consumers and acting as a catalyst in reactions of EC formation (MAPA, 2011).

The Sectorial Chamber of the Cachaça Productive Chain in Brazil was created to reduce ethyl car- bamate (EC) and $\mathrm{Cu}$ in cachaça. Ethyl carbamate or urethane $\left(\mathrm{H}_{2} \mathrm{NCOOC}_{2} \mathrm{H}_{5}\right)$ is potentially carcinogenic to humans and is formed naturally in fermented foods and beverages (Schlatter and Lutz, 1990). Brazil is the world's fourth largest producer of distilled alcoholic beverages and cachaça is the main Brazilian product of this sector. The high production of cachaça and the importance to comply with export requirements, the EC content should be monitored to remain within the thresholds permitted by international legislation and consuming countries. This review describes cachaça production and identifies EC formation at various stages of the production process, indicating that more research is needed to avoid high concentrations of EC in cachaça.

\section{Cachaça}

Brazil, due to its location in the tropical region, has great capacity to produce vegetal biomass, for instance, sugarcane crops (Machado and Margarido, 2008). The expansion of sugarcane production requires agricultural methods that cause little damage to the environment, allowing sustainable practices. In Brazil, sugarcane is widely cultivated as a monoculture system, which explores the soil in a single crop, known as conventional management. Monoculture uses soil preparation techniques such as plowing, liming, sorting, sowing, mineral fertilization and agricultural pesticides. In recent years, this system has been disapproved due to its negative impacts on socio-environment and human health. Studies point to alternative systems for sugarcane production, for example, organic agriculture, which provides economic interaction with more balanced ecosystems, biodiversity preservation of improved biological activities in the soil (MAPA, 2003). 
Sugarcane is the raw material used in cachaça production. Cachaça is highly appreciated by consumers in Brazil, Europe, and in South and North America. Brazil has an installed capacity to produce approximately 1.2 billion liters of cachaça per year. However, the country produces less than 800 million liters and exports roughly 8.7 million liters produced by almost 12,000 producers (IBRAC, 2017). The origin of cachaça is linked to colonization of Brazil and is directly related to sugar production from sugar cane. Cachaça uses sugar cane as raw material, which enabled the introduction of stills and therefore is considered as a fundamental beverage in the Brazilian history with great cultural, social and economic importance. Several studies report the emergence of cachaça and its etymology in Brazil (Trindade, 2006; Silva et al., 2014).

Since cachaça origin in Brazil, there have been no concerns with the quality of physical-chemical properties and very little concern with sensory aspects.

Today, cachaça is a drink enjoyed by all social classes and has better quality than before. The factors that define cachaça quality are raw material, climatic conditions, cultivation, and the production process. It is common for cachaça produced in different Brazilian regions to present differences in quantities of chemical compounds and sensory attributes (Reche and Franco, 2009). Cachaça is highly appreciated by Brazilians and experts in the area know the difference between the kinds produced; however, most people classify both beverages as the same. In this context, Decree No. 6,871 of 4 June 2009 of the Presidency of the Republic of Brazil, regulates Law No. 8,918 of 14 July 1994, which provides procedures for standardization, classification, registration, inspection, and production of beverages, defined as:

"Cachaça is the typical and exclusive denomination of cane brandy produced in Brazil, with an alcoholic degree between 38 and $54 \%$ per volume, at $20^{\circ} \mathrm{C}$, obtained by distillation of fermented sugarcane must with peculiar sensory characteristics, with addition of up to 6 gr of sugars per liter (MAPA, 2009)."

In order to develop a productive cachaça chain and to ensure its composition and quality, the Ministério da Agricultura, Pecuária e Abastecimento (MAPA) established the Normative Instruction No. 13 of 29 June 2005, which approves the technical regulation for identity and quality standards of cachaça and sugarcane brandy. The low concentration of contaminating compounds is intrinsic to the chemical quality of cachaça. The main contaminants are $\mathrm{Cu}$, methanol, n-butanol, sec-butanol and EC.

Cachaça consumers are more demanding; thus, the beverage sector in Brazil has invested in technological development for its production. These investments have provided improvements in quality and international recognition of cachaça, earning the status of a fine quality drink (Silva et al., 2014). International appreciation of cachaça has led public institutions, the private sector and representatives of the Federal Government directly involved in the cachaça production chain to create Sectorial Chamber of the Cachaça Productive Chain related to MAPA, responsible for quality and development of beverages in Brazil. This Sectorial Chamber promoted collective work to improve the production chain of this beverage (MAPA, 2011).

\section{Ethyl carbamate (EC)}

Ethyl carbamate, also known as urethane, belongs to the group of organic compounds classified as ethyl esters of carbamic acid $\left(\mathrm{H}_{2} \mathrm{NCOOH}\right)$. Ethyl carbamate $\left(\mathrm{H}_{2} \mathrm{NCOOC}_{2} \mathrm{H}_{5}\right)$ has been the subject of great interest in the scientific community due to its toxicity, prompting research to its characterization, quantification and application (Baffa Júnior et al., 2011). EC is found in cachaça, whiskey, rum, vodka, staple, tequila, beer, as well as in cherries in syrup, bread, yogurt and others. The precursors of EC in cachaça arise from many factors or steps in the production process, from raw material to the way of beverage storage. The presence of $\mathrm{Cu}$ (a catalyst in EC formation) in cachaça is intrinsic to the process, because it is largely used to make alembic stills; however, lack of GMP contributes to a higher incidence of this contaminant in the beverage (Lawrence et al., 1990).

Copper can be found in fermented products and several natural precursors can promote its formation in the production process and storage of the product. EC was first synthesized in the $19^{\text {th }}$ century as a colorless, odorless crystal, with a salty and slightly bitter taste. EC has distinct commercial applications, as co-solvent for pesticides, in cosmetics and in drug synthesis (Ghanayem, 2007). In medicine, in the early 1940s, EC was used as hypnotic in humans, as anesthetic in animals and as antineoplastic agent for treating myeloma. Several studies directly relate EC to carcinogenic and other harmful actions to human health (Nettleship and Henshaw, 1943; Baffa Júnior et al., 2011; Forkert et al., 2007).

The International Agency for Research on Cancer (IARC), based on several studies reporting the toxicity of EC, placed it into class $2 \mathrm{~B}$, a group of substances that are carcinogenic to humans (Alexander et al., 2007).

\section{Cachaça production}

According to the Instituto Brasileiro de Geografia e Estatística (IBGE), the beverage sector in Brazil is classified into five categories of economic importance: no alcoholic beverages with $47 \%$, beers with $41 \%$, spirits and other distilled beverages with $7 \%$, wines with $2.5 \%$ and mineral water with $2.5 \%$. In Brazil, the distilled beverage segment is commercially important. In this category, cachaça leads the rank of volume production in the market with $87 \%$, followed by whiskey $(13 \%)$, brandy $(5.4 \%)$, vodka $(2.5 \%)$, rum bitters $(0.7$ $\%)$, gin $(0.1 \%)$ and others $(0.5 \%)$ (Cervieri Júnior et al., 2014). 
In a study, the Serviço Brasileiro de Apoio às Micro e Pequenas Empresas (SEBRAE, 2012) showed 40,000 registered and legalized producers of cachaça in Brazil, $98 \%$ classified as small and micro businesses. This segment generates 600,000 direct or indirect jobs in the country and revenues of roughly US $\$ 17$ billion in the entire production chain. The annual per capita consumption of cachaça in Brazil is $6.29 \mathrm{~L}$, which can be considered small when compared to $85 \mathrm{~L}$ for soft drinks, the leading sector, followed by beer with 70 L. However, a Brazilian who consumes approximately $6 \mathrm{~L}$ of cachaça a year ingests $1.2 \mathrm{mg} \mathrm{L}^{-1}$ of EC, considerably higher than that the threshold established by legislation $\left(0.21 \mathrm{mg} \mathrm{L}^{-1}\right)$.

Cachaça is the fourth most consumed distilled beverage in the world, with an annual production of roughly 800 million liters and around 8.7 million liters exported (IBRAC, 2017).

Figure 1 briefly shows the production of cachaça from sugarcane planting to beverage production to the consumer. EC formation relates to the most important processing steps.

\section{Planting, harvesting and milling of sugarcane}

Because of the different relationships between the environment and living beings, sugarcane planting varies among regions of Brazil (Andrade, 2006). Thus, it was necessary to determine periods to plant throughout the year in order to obtain the best agricultural and industrial yields, depending on the harvest (Lima and Garcia, 2011). The choice of sugarcane variety is the most important and least costly step in cachaça production. A study that evaluated sugarcane varieties, harvested at different times for cachaça production, showed that sugarcane variety influences the chemical composition of sugarcane juice and subsequently the product (Fernandes et al., 2017).

For planning the crop, the area of cultivation is normally calculated based on the average of the agricul- tural yield over three consecutive harvests, harvesting period, industrial yield and daily production of cachaça (Lima et al., 2001; Santos and Borém, 2013; Landell and Bressiani, 2008)

Sugarcane industries use organic and conventional (mineral) fertilizers in sugarcane crops. In mineral fertilization, nitrogenous compounds are used. Nitrogen is a key element in the formation of biomolecules, such as proteins, amino acids and nucleic acids. Nitrogen is found in the soil in gaseous form not available to the plant and as ammoniacal nitrogen and ammonium and nitrate ions, which are readily assimilated by plants.

Nitrogen is involved in one of the pathways of EC formation in cachaça; however, studies on quantification of EC in cachaça did not present significant differences of $\mathrm{N}$-fertilized sugarcane compared to non-fertilized (Machado et al., 2014; Souza, 2013).

Sugarcane harvesting should consider the economic return and the best harvesting period is related to the highest sucrose concentration in culms. Sugarcane harvesting with a soluble solids concentration below $18{ }^{\circ}$ Brix (estimated $14 \%$ sucrose) is not economically desirable, while above $18{ }^{\circ}$ Brix is considered suitable (Lima et al., 2001; Andrade, 2006).

\section{Grinding and fermentation}

In cachaça production, extraction of sugarcane juice occurs by crushing the cane directly from the miller to the diffuser. In the production process, the factors that most contribute to quality variation of distilled alcoholic beverages, such as cachaça, encompass all operations and processes, namely reception of raw material and milling, fermentation, distillation and aging.

Fermentation is considered one of the most important operations because it directly influences the chemical and sensorial composition of alcoholic beverages. During fermentation, chemical constituents of the drink are produced (Cardoso, 2013).

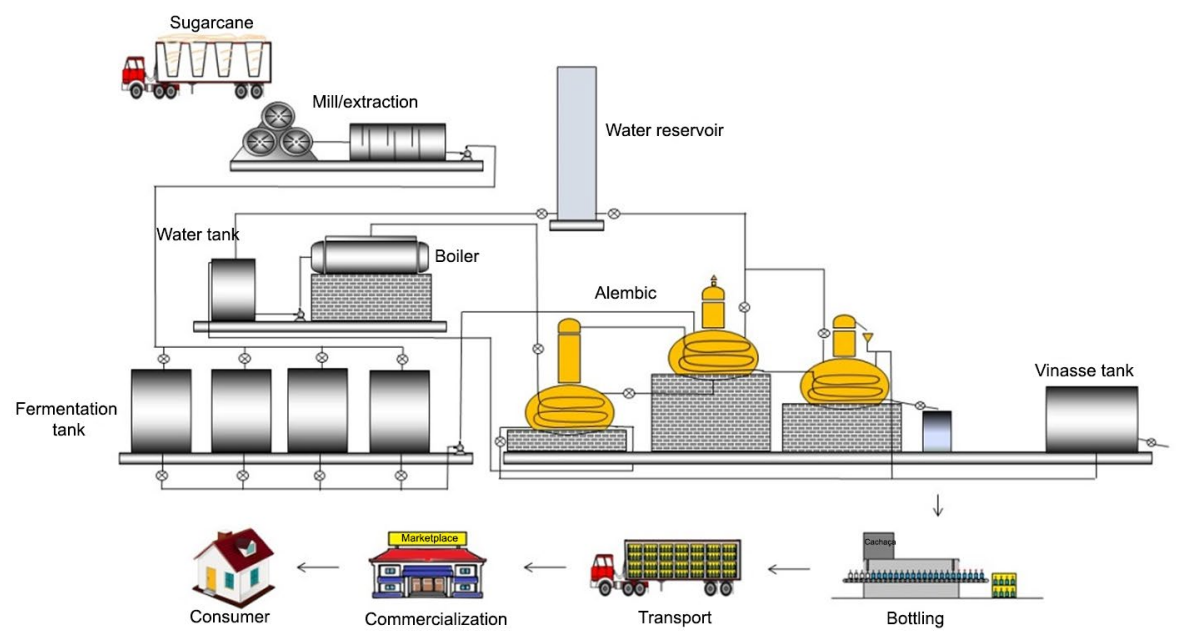

Figure 1 - Cachaça production scheme. 
Natural fermentation musts is difficult, as it requires inoculation with a fermentation agent and Saccharomyces cerevisiae is the most widely used in cachaça production (Alcarde et al., 2014). In cachaça production, there are several possible pathways for EC formation, including the reaction between ethanol and nitrogenous precursors, such as urea $\left(\mathrm{H}_{2} \mathrm{NCONH}_{2}\right)$ and cyanide $\left(\mathrm{CN}^{-}\right)$ (Zimmerli and Schlatter, 1991; Cook et al., 1990; Aylott et al., 1990; Mackenzie et al., 1990).

Urea has been widely used as a protein source for yeast in the fermentation process. The hydro alcoholic solution forms isocyanate $\left(\mathrm{NCO}^{-}\right)$and cyanate $\left(\mathrm{CNO}^{-}\right)$ ions react with ethanol, forming the EC (Eq. 1), when it undergoes thermal decomposition (between 60 and 100 $\left.{ }^{\circ} \mathrm{C}\right)$. In another route, the urea undergoing thermal decomposition forms ammonia $\left(\mathrm{NH}_{3}\right)$ and isocyanic acid (HCNO) that react with ethanol, forming EC (Eq. 2) (Zimmerli and Schlatter, 1991; Bruno et al., 2007; Weber and Sharypov, 2009; Lachenmeier et al., 2009; Riffkin et al., 1989a; Schaber et al., 2004; Aresta et al., 2001).

$\mathrm{Cu}(\mathrm{CNO})_{2}+2 \mathrm{H}_{2} \mathrm{O} \rightarrow \mathrm{Cu}\left(\mathrm{OOCNH}_{2}\right)_{2}$

$\mathrm{HNCO}+\mathrm{C}_{2} \mathrm{CH}_{5} \mathrm{OH} \vec{\Delta} \mathrm{NH}_{2} \mathrm{COOCH}_{2} \mathrm{CH}_{3}$

$$
\begin{aligned}
& \mathrm{HNCO}+\mathrm{C}_{2} \mathrm{CH}_{5} \mathrm{OH} \vec{\Delta} \mathrm{NH}_{2} \mathrm{COOCH}_{2} \mathrm{CH}_{3} \\
& \mathrm{H}^{+}+\mathrm{OCN}^{-} \rightleftharpoons \mathrm{HOCN} \rightleftharpoons \mathrm{HNCO} \\
& \mathrm{HNCO}+\mathrm{C}_{2} \mathrm{CH}_{5} \mathrm{OH} \rightarrow \mathrm{NH}_{2} \mathrm{COOCH}_{2} \mathrm{CH}_{3}
\end{aligned}
$$

Another way that involves the cyanide ion $\left(\mathrm{CN}^{-}\right)$in EC formation occurs by the enzymatic action and oxidation of cyanogenic glycosides. Cyanogenic glycosides are produced by more than 2,000 plant species, such as rice, sugar cane, barley, malt, cassava, among others (Cook et al., 1990). Cyanogenic glycosides are found in sugarcane by means of enzymatic action, producing sugar and cyanodrine $\left[\mathrm{R}_{2} \mathrm{C}(\mathrm{OH}) \mathrm{CN}\right]$ that decompose into cyanide $\left(\mathrm{CN}^{-}\right)$ion, which is oxidized to cyanate ion (CNO) that reacts with ethanol $\left(\mathrm{C}_{2} \mathrm{H}_{5} \mathrm{OH}\right)$ and produces EC (Eq. 3) (Zimmerli and Schlatter, 1991; Weber and Sharypov, 2009; Orduña et al., 2000; Uthurry et al., 2006; Bradbury, 2009; Galinaro and Franco, 2011).

$$
\begin{aligned}
& \mathrm{R}-\mathrm{C} \equiv \mathrm{N} \underset{\text { Enzymatic action }}{\longrightarrow} \mathrm{HCN} \equiv \mathrm{N} \underset{\text { Oxidation }}{\longrightarrow} \mathrm{OH}-\mathrm{C} \equiv \mathrm{N} \\
& \mathrm{OH}-\mathrm{C} \equiv \mathrm{N}+\mathrm{HNCO}+\mathrm{C}_{2} \mathrm{CH}_{5} \mathrm{OH} \rightarrow \mathrm{NH}_{2} \mathrm{COOCH}_{2} \mathrm{CH}_{3}
\end{aligned}
$$

\section{Distillation}

In cachaça production, distillation separates ethanol from wine (hydroalcoholic solution). Wine distillation is based on three fundamentals: boiling point, affinity with alcohol or water, and alcoholic content during distillation (Gabriel et al., 2012).

Cachaça distillation carried out in alembic stills produces different fractions, which are classified into 'head', which corresponds to 8 to $10 \%$ of the total vol- ume of still wine; 'heart', which corresponds to $80 \%$ of the volume and 'tail', which corresponds to 8 to $10 \%$ of the total wine volume (Masson et al., 2012). The main requirement for a good quality cachaça is to know the exact separation of the heart phase from the other two fractions (Alcarde et al., 2012a; Faria and Lourenço, 1990).

Cyanide ion $\left(\mathrm{CN}^{-}\right)$is a precursor of EC during and after distillation. The reaction involves the oxidation of cyanide $\left(\mathrm{CN}^{-}\right)$to cyanate $\left(\mathrm{CNO}^{-}\right)$that reacts with ethanol $\left(\mathrm{C}_{2} \mathrm{H}_{5} \mathrm{OH}\right)$ to form EC (Mackenzie et al., 1990).

EC formation inside the apparatus for $\mathrm{Cu}$ distillation occurs by the reaction presented in equations below, where $\mathrm{Cu}$ is oxidized and acts as a catalyst. The reaction begins when the hydrocyanic acid reaches the condenser and is complexed with $\mathrm{Cu}$ ion II $\left(\mathrm{Cu}^{2+}\right)$. The $\mathrm{Cu}$ ion is formed by the oxidation of the condenser by acid vapors from wine, generating the cyanide $\mathrm{Cu}$ ion $\left[\mathrm{Cu}(\mathrm{CN})_{2}\right]$ (Eq. 4), followed by an oxidation in cyanogen $\left[(\mathrm{CN})_{2}\right]$ (Eq. 5), which can oxide in cyanate $\left(\mathrm{OCN}^{-}\right)$and cyanide $(\mathrm{CN})$ ions (Eq. 6). Finally, the cyanate ion $\left(\mathrm{OCN}^{-}\right.$ I in acidic medium can react with ethanol $\left(\mathrm{C}_{2} \mathrm{H}_{5} \mathrm{OH}\right)$ and form $\mathrm{EC}\left(\mathrm{C}_{2} \mathrm{H}_{5} \mathrm{OCONH}_{2}\right)$ (Eq. 7) (Bruno et al., 2007; Weber and Sharypov, 2009; Aresta et al., 2001; Beattie and Polyblank, 1995).

$$
\begin{aligned}
& 4 \mathrm{CN}^{-}+2 \mathrm{HCu}^{2+} \rightarrow 2 \mathrm{Cu}(\mathrm{CN})_{2} \\
& 2 \mathrm{Cu}(\mathrm{CN})_{2} \rightarrow 2 \mathrm{Cu}(\mathrm{CN})+(\mathrm{CN})_{2} \\
& (\mathrm{CN})_{2}+\mathrm{H}_{2} \mathrm{O} \rightarrow \mathrm{OCN}^{-}+\mathrm{CN}^{-}+2 \mathrm{H}^{+} \\
& \mathrm{OCN}^{-}+\mathrm{C}_{2} \mathrm{CH}_{5} \mathrm{OH}+\mathrm{H}^{+} \rightarrow \mathrm{C}_{2} \mathrm{H}_{5} \mathrm{OCONH}_{2}
\end{aligned}
$$

Formation of EC in the distillation apparatus can also originate from $\mathrm{Cu}$ II cyanate $\left[\mathrm{Cu}(\mathrm{CNO})_{2}\right]$ in aqueous medium by two routes. The first step occurs by reaction of cyanate anion $\left(\mathrm{OCN}^{-}\right)$with $\mathrm{Cu}$ and $\mathrm{N}$ atom $(\mathrm{N})$, generating the cyan complex of $\mathrm{Cu}$ II $\left[\mathrm{Cu}\left(\mathrm{OOCNH}_{2}\right)_{2}\right]$ (Eq. 8). The carbon atom $(\mathrm{C})$ is more electropositive since it is chemically bonded to $\mathrm{Cu}$; therefore, it facilitates the nucleophilic ethanol attack and forms $\mathrm{Cu}$ hydroxide II $\left[\mathrm{Cu}\left(\mathrm{OH}_{2}\right)\right]$ and EC $\left(\mathrm{C}_{2} \mathrm{H}_{5} \mathrm{OCONH}_{2}\right)$ (Eq. 9) (Weber and Sharypov, 2009; Aresta et al., 2001).

The second course comprises the chemical reaction between $\mathrm{Cu}$ cyanate II $\left[\mathrm{Cu}(\mathrm{CNO})_{2}\right]$ and ethanol $\left(\mathrm{C}_{2} \mathrm{H}_{5} \mathrm{OH}\right)$ producing a carbamic compound $[(\mathrm{OCN}) \mathrm{CuNHC}(\mathrm{O})$ $\mathrm{OC}_{2} \mathrm{H}_{5}$ ] (Eq. 10). This carbamic compound reacts to a water molecule $\left(\mathrm{H}_{2} \mathrm{O}\right)$ and produces $\mathrm{EC}\left(\mathrm{C}_{2} \mathrm{H}_{5} \mathrm{OCONH}_{2}\right)$ (Eq. 11) (Weber and Sharypov, 2009; Aresta et al., 2001).

$$
\begin{aligned}
& \mathrm{Cu}(\mathrm{CNO})_{2}+2 \mathrm{H}_{2} \mathrm{O} \rightarrow \mathrm{Cu}(\mathrm{OOCNH})_{2} \\
& \mathrm{Cu}(\mathrm{OOCNH})_{2}+\mathrm{C}_{2} \mathrm{CH}_{5} \mathrm{OH} \rightarrow 2 \mathrm{C}_{2} \mathrm{CH}_{5} \mathrm{OCONH}_{2} \mathrm{Cu}(\mathrm{OH})_{2}(9) \\
& \mathrm{Cu}(\mathrm{CNO})_{2}+\mathrm{C}_{2} \mathrm{CH}_{5} \mathrm{OH} \rightarrow(\mathrm{OCN}) \mathrm{CuNHC}(\mathrm{O}) \mathrm{OC}_{2} \mathrm{H}_{5} \\
& (\mathrm{OCN}) \mathrm{CuNHC}(\mathrm{O}) \mathrm{OC}_{2} \mathrm{H}_{5}+\mathrm{H}_{2} \mathrm{O} \rightarrow(\mathrm{OCNCu}(\mathrm{OH}))+ \\
& \mathrm{C}_{2} \mathrm{H}_{5} \mathrm{OCONH}_{2}
\end{aligned}
$$




\section{Storage and aging}

According to the Instituto Nacional de Metrologia, Qualidade e Tecnologia (INMETRO) in Brazil, cachaça could be stored in containers made of different materials, such as wood, stainless steel, or carbon steel with internal insulation in order to avoid contamination or evaporation of the beverage. Authors report that the EC levels in the product may be related to storage conditions of the beverage (Machado et al., 2014; Anjos et al., 2011; Oliveira Filho et al., 2016).

Aging is the final step in cachaça production. In this step, the drink increases in quality, as it acquires desirable attributes of color, aroma and taste (Parazzi et al., 2008). Cachaça aging in wooden barrels tempers the aroma and flavor through oxidation reactions of aldehydes formed during fermentation, which are responsible for the 'off' flavor that causes discomfort in the nasal mucosa (Yokoya, 1995). Many studies show that cachaça aging influences EC concentration. Therefore, cachaça aging may increase EC contents in this beverage (Machado et al., 2014). Was studied 25 types of cachaça of pot still cachaça from 19 distilleries in Paraíba State, Brazil. We found a concentration range of 55-700 $\mathrm{g} \mathrm{L} \mathrm{L}^{-1}$ in most cachaça (70 $\%)$. However, when we compared EC levels of yellowish (wooden barrel aging) and colorless cachaça from the same distillery, the aged beverage had a higher EC concentration (Nobrega et al., 2009). Researchers have evaluated EC concentration in cachaça aged in oak barrels (Quercus sp.) and glass bottles. Storage in oak barrels and no glass containers resulted in a significant increase in EC concentration (Anjos et al., 2011).

After the aging process, cachaça needs to be filtered and filtration has to eliminate suspended particles or impurities before the aging stage, providing greater transparency to the beverage (Dias, 2007).

In order to provide a quality product that can be reproduced, even using different harvests, a certification system for cachaça was needed (SEBRAE, 2017). The certification ensures compliance of the beverage with the legislation - the Regulation of Conformity Assessment (RCA). Certified cachaça receives a quality identification stamp, printed on the bottle label. The stamp indicates that certified beverages have been rigorously analyzed by physical-chemical analyses to control quality (SEBRAE, 2017; Soratto et al., 2007; Masson et al., 2012).

After filtration, cachaça is bottled, which proves the cachaça compliance with required specifications. New transparent glass bottles are recommended, usually 600 to $1,000 \mathrm{~mL}$ volume. For bottling, cachaça needs to be transferred to the bottle, which is then closed with a metal lid, stopper, or eyedropper. The bottle must have adequate identification and, if possible, an attractive label, and must contain relevant information for the consumer (MDIC, 2005).

Once the production process cycle is completed, cachaça is ready for to be marketed both domestically and internationally through retailers, mainly supermar- kets and/or bars. In Brazil, commercialization of distilled beverages can also be done through outlets, or wholesalers and distributors of beverages (Soratto et al., 2007).

\section{Changes in processes that minimize EC incidence}

Although this review describes the possible ways of EC formation in the different stages of cachaça production, it is also important to present some studies that focus on strategies for reducing this contaminant in alcoholic beverages.

Studies on the production process of alcoholic beverages and proposals for modifications in the production steps to minimize EC formation were started at the end of the 1980's.

Distillation in copper stills received special attention in the studies on influence of the production process on EC formation, since $\mathrm{Cu}$ is precursor of EC. Reduction of distillation time in copper stills in whiskey production was studied in order to minimize EC formation due to the reduction of contact time of the beverage with $\mathrm{Cu}$ in the distiller (Riffkin et al., 1989a). This research group also identified, in a model study, that when protein contents are higher in copper distiller, there is greater formation of EC (Riffkin et al., 1989b).

Aylott et al. (1990) demonstrated different ways of EC formation due to EC precursors during whiskey storage. The authors indicated that in order to decrease the amount of EC in the beverage, the monitoring of EC precursors is essential.

In cachaça production, several studies suggest variation of the process in order to decrease EC amount in the beverage. For example, double distillation has contributed to decrease EC amount in cachaça (Alcarde et al., 2012a). There are also suggestions for changes in the configuration of copper stills with different condensation systems. Double distillation with high reflux rates in stills resulted in a considerable reduction of EC in cachaça (Alcarde et al., 2012b).

Besides the monitoring of EC precursors in the production process and storage of beverages, identification of critical control points (CCPs) for good cachaça handling practices and implementation of the hazard analysis and critical control points (HACCP) in small distilleries have also been the focus of recent research aimed at implementation of a system to produce safe cachaça with low levels of contaminants (Bortoletto et al., 2018).

\section{Conclusion}

Ethyl carbamate is a potentially carcinogenic substance, thus, the topics addressed in this work indicate the urgent need for attention to the cachaça production process to eradicate this public health threat and comply the product with international standards. Only beverage monitoring throughout the production and storage processes allows a better evaluation of the origin of EC in cachaça and its minimization in the product. 
In the past, Scotch whiskeys also contained high EC levels and changes in the production process, proposed by specific legislation and consumer market pressure, have influenced quality improvement of the product. This occurred in Italy with grappa and is occurring in Brazil with cachaça. Therefore, concerns with EC content in cachaça have considered new investments in the stages of cachaça production. This development in the production chain is considered extremely positive to reach a new standard that guides consumers to make purchase decisions of a beverage less costly and higher quality.

\section{Acknowledgements}

We would like to thank Fundação de Amparo à Pesquisa do Estado de São Paulo (FAPESP), Project $n^{\circ}$ 2016/13460-8 and Conselho Nacional de Desenvolvimento Científico e Tecnológico (CNPq), Process: 306317/2016-8.

\section{Authors' Contributions}

Conceptualization: Silva, J.H.N.; Bernardi, M.R.V.; Oliveira, A.L. Data review: Silva, J.H.N. Writing and editing: Silva, J.H.N.; Bernardi, M.R.V.; Oliveira, A.L.

\section{References}

Alcarde, A.R.; Souza, L.M.; Bortoletto, A.M. 2014. Formation of volatile and maturation-related congeners during the aging of sugarcane spirit in oak barrels. Journal of the Institute of Brewing 120: 529-536.

Alcarde, A.R.; Souza, L.M.; Bortoletto, A.M. 2012a. Ethyl carbamate kinetics in double distillation of sugar cane spirit. Journal of the Institute of Brewing 118: 27-31.

Alcarde, A.R.; Souza, L.M.; Bortoletto, A.M. 2012b. Ethyl carbamate kinetics in double distillation of sugar cane spirit. Part 2. Influence of type of pot still. Journal of the Institute of Brewing 118: 352-355.

Alexander, J.; Audunsson, G.A.; Benford, D.; Cockburn, A.; Cravedi, J.P.; Dogliotti, E.; Domenico, A.; Férnandez-Cruz, M.F.; Fürst, P.; Fink-Gremmels, J.; Galli, C.L.; Grandjean, P.; Gzyl, J.; Heinemeyer, G.; Johansson, N.; Mutti, A.; Schlatter, J.; Leeuwen, R.V.; Peteghem, C.V.; Verger, P. 2007. Opinion of the Scientific Panel on Contaminants in the Food chain on a request from the European Commission on ethyl carbamate and hydrocyanic acid in food and beverages. EFSA Journal 55: $1-44$.

Andrade, L.A.B. 2006. Culture of sugarcane = Cultura da Canade-açúcar. p. 25-55. In: Cardoso, M.G., ed. Production spirit sugarcane = Produção de aguardente de cana-de-açúcar. UFLA, Lavras, MG, Brazil (in Portuguese).

Anjos, J.P.D.; Cardoso, M.D.G.; Saczk, A.A.; Zacaroni, L.M.; Santiago, W.D.; Dórea, H.S.; Machado, A.M.D.R. 2011. Identification of ethyl carbamate during storage of cachaça in oak barrels (Quercus sp.) and glass container. Química Nova 34: 874-878 (in Portuguese, with abstract in English).
Aresta, M.; Boscolo, M.; Franco, D.W. 2001. Cooper (II) catalysis in cyanide conversion into ethyl carbamate in spirits and relevant reactions. Journal of Agricultural and Food Chemistry 49: 2819-2824.

Aylott, R.I.; Cochrane, G.C.; Leonard, M.J.; MacDonald, L.S.; MacKenzie, W.M.; McNeish, A.S.; Walker, D.A. 1990. Ethyl carbamate formation in grain based spirits. Part I. Postdistillation ethyl carbamate formation in maturing grain whisky. Journal of the Institute of Brewing 96: 213-221.

Baffa Júnior, J.C.; Mendonça, R.C.; Pereira, J.M.A.T.K.; Pereira, J.A.M.; Soares, N.F.F. 2011. Ethyl-carbamate determination by gas chromatography mass spectrometry at different stages of production of a traditional Brazilian spirit. Food Chemistry 129: 1383-1387.

Beattie, J.K.; Polyblank, G.A. 1995. Copper-catalyzed oxidation of cyanide by peroxide in alkaline aqueous solution. Australian Journal of Chemistry 48: 861-868.

Bortoletto, A.M.; Silvello, G.C.; Alcarde, A.R. 2018. Good manufacturing practices, hazard analysis and critical control point plan proposal for distilleries of cachaça. Scientia Agricola 75: 432-443.

Bradbury, J.H. 2009. Development of a sensitive picrate method to determine total cyanide and acetone cyanohydrin contents of gari from cassava. Food Chemistry 113: 1329-1333.

Bruno, S.N.F.; Vaitsman, D.S.; Kunigami, C.N. 2007. Influence of distillation processes from in the ethyl carbamate formation in Brazilian sugar cane spirits. Food Chemistry 104: 13451352.

Cardoso, M.D.G. 2013. Production of Spirit Sugarcane = Produção de Aguardente de Cana. UFLA, Lavras, MG, Brazil (in Portuguese).

Cervieri Júnior, O.; Teixeira Júnior, J.R.; Galinari, R.; Rawet, E.L.; Silveira, C.T.J. 2014. The Beverage Industry in Brazil = O Setor de Bebidas no Brasil. BNDES, Brasília, DF, Brazil (in Portuguese).

Cook, R.; McCaig, N.; McMillan, J.M.B.; Lumsden, W.B. 1990. Ethyl carbamate formation in grain-based spirits: the primary source. Journal of the Institute of Brewing 96: 233-244.

Dias, T. 2007. Beverages free of impurities. Filter Media 5: 2527.

Faria, J.B.; Lourenço, E.J. 1990. Influence of copper on the composition of sugar cane brandy (Saccharumofficinarum L.) = Influência do cobre na composição da aguardente de cana. Alimentos e Nutrição 2: 93-100 (in Portuguese).

Fernandes, O.W.B.; Silva, D.F.; Sanson, A.L.; Coutrim, M.X.; Afonso, R.J.C.F.; Eichler, P. 2017. Influence of harvest season and maturation of different sugarcane (Saccharum spp.) cultivars on the chemical composition of alembic Brazilian sugarcane spirit. Open Access Library Journal 4: 1-16.

Forkert, P.G.; Kaufmann, M.; Black, G.; Bowers, R.; Chen, H.; Collins, K.; Jones, G. 2007. Oxidation of vinyl carbamate and formation of 1, N6-ethenodeoxyadenosine in murine lung. Drug Metabolism and Disposition 35: 713-720.

Gabriel, A.V.M.D.; Verruma-Bernardi, M.R.; Margarido, L.A.C.; Borges, M.T.M.R.; Nassu, R.T.; Lavorenti, N.A.; CeccatoAntonini, S.R. 2012. Effect of the spontaneous fermentation and the ageing on the chemo-sensory quality of Brazilian organic cachaça. Ciência Rural 42: 918-925. 
Galinaro, C.A.; Franco, D.W. 2011. Formation of ethyl carbamate in freshly distilled spirits: proposal for its control. Química Nova 34: 996-1000 (in Portuguese, with abstract in English).

Ghanayem, B.I. 2007. Inhibition of urethane-induced carcinogenicity in Cyp2e1-/- in comparison to Cyp $2 e 1+/+$ mice. Toxicological Sciences 95: 331-339.

Instituto Brasileiro da Cachaça [IBRAC]. 2017. Intern market = Mercado interno. Available at: http://www.ibrac.net/index. php/servicos/estatisticas/mercado-interno [Accessed July 23, 2018] (in Portuguese).

Lachenmeier, D.W.; Kuballa, T.; Lima, M.C.; Nobrega, I.C.; Kerr-Corrêa, F.; Kanteres, F.; Rehm, J. 2009. Ethyl carbamate analysis in German fruit spirits and Brazilian sugarcane spirits (cachaça): improved sample cleanup with automated parallel evaporation. Deutsche Lebensmittel-Rundschau 105: 507-512.

Landell, M.G.A.; Bressiani, J.A. 2008. Genetic improvement, characterization and varietal management $=$ Melhoramento genético, caracterização e manejo varietal. p. 101-155. In: Dinardo-Miranda, L.L.; Vasconcelos, A.C.M.; Landell, M.G.A., eds. Sugarcane $=$ Cana-de-Açúcar. Instituto Agronômico, Campinas, SP, Brazil (in Portuguese).

Lawrence, J.F.; Page, B.D.; Conacher, H.B.S. 1990. The formation and determination of ethyl carbamate in alcoholic beverages. Environmental Science and Technology 23: 457-478.

Lima, U.D.A.; Basso, L.C.; Amorim, H.D. 2001. Production of ethanol = Produção de etanol. p. 1-43. In: Lima, U.A.; Aquarone, E.; Borzani, W.; Schimidell Netto, W., eds. Industrial biotechnology: enzymatic and fermentative processes = Biotecnologia industrial: processos enzimáticos e fermentativos. Edgard Blucher, São Paulo, SP, Brazil (in Portuguese).

Lima, D.A.L.L.; Garcia, J.R. 2011. The evolution of sugarcane production and the impact on land use in the state of Goiás = A evolução da produção da cana-de-açúcar e o impacto no uso do solo no estado de Goiás. Social and Agricultural Study 19: 374-403 (in Portuguese).

Machado, R.; Margarido, L.A.C. 2008. Assays of Organic Production Systems for Sugarcane Soca, using the consortium technique = Ensaios de sistemas orgânicos de produção de cana-de-açúcar Soca, utilizando a técnica do consórcio. Cadernos de Agroecologia 9: 1-11 (in Portuguese).

Machado, A.M.R.; Cardoso, M.G.; Dorea, H.S.; Emidio, E.S.; Silva, M.M.S.; Anjos, J.P.; Saczk, A.A.; Nelson, D.L. 2014. Contamination of cachaça by PAHs from storage containers. Food Chemistry 146: 65-70.

Mackenzie, W.M.; Clynne, A.H.; McDonald, L.S. 1990. Ethyl carbamate formation in grain based spirits. Part II. The identification and determination of cyanide related species involved in ethyl carbamate formation in Scoth whisky. Journal of the Institute of Brewing 96: 213-221.

Masson, J.; Cardoso, M.D.G.; Zacaroni, L.M.; Anjos, J.P.D.; Sackz, A.A.; Machado, A.M.D.R.; Nelson, D.L. 2012. Determination of acrolein, ethanol, volatile acidity, and copper in different samples of sugarcane spirits. Food Science and Technology 32: 568-572.

Ministério da Agricultura, Pecuária e Abastecimento [MAPA]. 2003. Law 10,831, provides for organic agriculture and provides other measures $=$ Lei $\mathrm{n}^{\circ} 10.831$, prevê a agricultura orgânica e fornece outras medidas. Diário Oficial da União, Brasília, DF, Brazil (in Portuguese).
Ministério da Agricultura, Pecuária e Abastecimento [MAPA]. 2005. Normative Instruction $n^{\circ}$. 13. Technical regulation for the definition of identity and quality standards for spirit sugar cane and cachaça $=$ Instrução normativa $\mathrm{n}^{\circ} 13$. Regulamentação técnica para a definição de padrões de identidade e qualidade para aguardente de cana e cachaça. Diário Oficial da União, Brasília, DF, Brazil (in Portuguese).

Ministério da Agricultura, Pecuária e Abastecimento [MAPA]. 2009. Decree $N^{\circ} .6,871$, which regulates Law $N^{\circ} .8,918$ of July 14,1994 , which provides for the standardization, classification, registration and inspection, production of beverages $=$ Decreto $\mathrm{n}^{\circ} 6.871$ que regulamenta a Lei $\mathrm{n}^{\circ} 8.918$ de 14 de julho de 1994 , que prevê a padronização, classificação, registros e inspeção, produção de bebidas. Diário Oficial da União, Brasília, DF, Brazil (in Portuguese).

Ministério da Agricultura, Pecuária e Abastecimento [MAPA]. 2011. Strategic agenda cachaça 2010-2015 = Agenda estratégica cachaça 2010-2015. MAPA/ACS, Brasília, DF, Brazil (in Portuguese).

Ministério da Indústria, Comércio Exterior e Serviços [MDIC]. 2005. Portaria $\mathrm{N}^{\circ} 126$, approves the regulation to evaluate the conformity of cachaça $=$ Portaria $\mathrm{N}^{\circ} 126$, aprova o regulamento para avaliar a conformidade da cachaça. Diário Oficial da União, Brasília, DF, Brazil (in Portuguese).

Nettleship, A.; Henshaw, P.S. 1943. Induction of pulmonary tumors in mice with ethyl carbamate (urethane). Journal of the National Cancer Institute 4: 309-19.

Nobrega, C.C.J.; Pereira, A.P.; Paiva, J.E. 2009. Ethyl carbamate in pot still cachaças (Brazilian sugar cane spirits): influence of distillation and storage conditions. Food Chemistry 117: 693697.

Oliveira Filho, J.H.; Bortoletto, A.M.; Alcarde, A.R. 2016. Postharvest quality of stored sugarcane stalks and their reflection on the production of cane spirit $=$ Qualidade pós-colheita de colmos de cana armazenados e seus reflexos na produção de cachaças. Brazilian Journal of Food Technology 19: e2015069 (in Portuguese).

Orduña, R.M.; Liu, S.Q.; Patchett, M.L.; Pilone, G.J. 2000. Ethyl carbamate precursor citrulline formation from arginine degradation by malolactic wine lactic acid bacteria. FEMS Microbiology Letters 183: 31-35.

Parazzi, C.; Arthur, C.M.; Lopes, J.J.C.; Borges, M.T.M.R. 2008. Evaluation and characterization of the main chemical compounds of sugar cane brandy aged in oak barrels (Quercus sp.). Food Science and Technology 28: 193-199 (in Portuguese, with abstract in English).

Reche, R.V.; Franco, D.W. 2009. Distinction between cachaças distilled in pot stills and in columns using chemometrics. Química Nova 32: 332-336 (in Portuguese, with abstract in English).

Riffkin, H.L.; Wilson, R.; Howie, D.; Muller, S.B. 1989a. Ethyl carbamate formation in the production of pot still whisky. Journal of the Institute of Brewing 95: 115-119.

Riffkin, H.L.; Wilson, R.; Bringhurst, T.A. 1989b. The possible involvement of $\mathrm{Cu} 2+$ peptide/protein complexes in the formation of ethyl carbamate. Journal of the Institute of Brewing 95: 121-122. 
Santos, F.; Borém, A. 2013. Sugar Cane: From Planting to Harvesting = Cana-de-Açúcar: do Plantio a Colheita. UFV, Viçosa, MG, Brazil (in Portuguese).

Schaber, P.M.; Colson, J.; Higgins, S.; Thielen, D.; Anspach, B.; Brauer, J. 2004. Thermal decomposition (pyroysis) of urea in an open reaction vessel. Thermochimica Acta 42: 131-142.

Schlatter, J.; Lutz, W.K. 1990. The carcinogenic potential of ethyl carbamate (urethane)-risk assessment at human dietary exposure levels. Food Chemistry Toxicology 28: 205-211.

Serviço Brasileiro de Apoio às Micro e Pequenas Empresas [SEBRAE]. 2012. Craft cachaça: series marketing studies = Cachaça artesanal: estudos e marketing em series. Available at: http://www.bibliotecas.sebrae.com.br/chronus/ARQUIVOS_ CHRONUS/bds/bds.nsf/444c2683e8debad2d7f38f49e848f449/ \$File/4248.pdf [Accessed Apr 27, 2017] (in Portuguese).

Serviço Brasileiro de Apoio às Micro e Pequenas Empresas [SEBRAE]. 2017. Culture of sugarcane = Certificação de Alambiques de cachaça. Available at: http://www.bibliotecas. sebrae.com.br/chronus/ARQUIVOS_CHRONUS/bds/bds.nsf/0 8EF03D0C42761248325763F0062D66F/\$File/NT0004292E.pdf [Accessed Apr 17, 2017] (in Portuguese).

Silva, J.H.N.; Verruma-Bernardi, M.R.; Borges, M.T.M.R.; Margarido, L.A.C. 2014. Influence of the prepare of sugarcane in the organic sugarcane cachaça = Influência do preparo da cana-de-açúcar na cachaça orgânica. UNAR 9: 1-14. (in Portuguese).
Soratto, A.N.; Varvakis, G.; Horii, J. 2007. Certification adds value to Brazilian "cachaça". Ciência e Tecnologia de Alimentos 27: 681-687 (in Portuguese, with abstract in English).

Trindade, A.G. 2006. Cachaça, a Brazilian Love = Cachaça, um Amor Brasileiro: história, fabricação, receitas. Melhoramentos, São Paulo, SP, Brazil (in Portuguese).

Uthurry, C.A.; Lepe, J.S.; Lombardero, J.; Del Hierro, J.G. 2006. Ethyl carbamate production induced by selected yeasts and lactic acid bacteria in red wine. Food Chemistry 94: 262-270.

Weber, J.V.; Sharypov, V.I. 2009. Ethyl carbamate in foods and beverages: a review. Environmental Chemical Letters 7: 233247.

Yokoya, F. 1995. Manufacture of cane spirit = Manufatura da aguardente de cana. Fundação André Tosello, Campinas, SP, Brazil (in Portuguese).

Zimmerli, B.; Schlatter, J. 1991. Ethyl carbamate: analytical methodology, occurrence formation, biological activity and risk assessment. Mutation Research 259: 325-50. 